\title{
RISK SHARING, TRANSFER AND MANAGEMENT
}

\author{
Abdul Karim Abdullah (Leslie Terebessy)*
}

\begin{abstract}
Risk management is a complex discipline with claimed scientific underpinnings. Since 2008 these have been shaken by the global financial crisis, with the result that some of the key paradigmatic assumptions of risk management are now seriously questioned. Major casualties of the crisis have been the views that credit markets are efficient, and that the best way to manage risk is to transfer it to someone else. With these assumptions increasingly in doubt, the current flawed paradigm of risk management is ripe for a rehabilitation that might bring the world's financial situation more in line with reality. The central question moving forward today is whether the right lessons will be drawn from the recent (2008) experience, and whether enough momentum can be generated to move to a new paradigm, one of risk sharing rather than risk transfer. This article explores the economic and financial dimensions of risk management and risk transfer, and then juxtaposes this review with a step-by-step survey of Islamic Finance's teachings on the related - and paradigm setting - notion of risk sharing. Risk sharing ensures an efficient allocation of resources and a reduction of waste by providing investors with a powerful incentive-the risk of losses-to exercise due diligence. At the same time, by requiring a greater number of parties to share total risk, risk sharing enhances systemic stability. These constitute compelling reason for utilising risk-sharing contracts in preference to risk transfer modes of risk management.
\end{abstract}

\section{Introduction}

The reliability of any science depends, among other things, on the firmness of its foundations. The science of risk management, which has developed into a complex discipline, is no exception. The assumptions underlying conventional risk management are generally rarely questioned. The recent global financial crisis of 2008, however, has laid bare some problematic assumptions, not only in risk management, but also more generally in finance. The chief of these assumptions in risk management is that the best way to manage risk is by transferring it to someone else.

Thomas Kuhn noted some years ago that every scientific paradigm (worldview) is only as credible as its underlying assumptions. ${ }^{1}$ Sometimes, unwarranted assumptions may become incorporated into a given paradigm. Such assumptions constitute anomalies within a given paradigm. Weaknesses within a given paradigm, however, eventually cause it to fail. The paradigm fails in the sense that when tested in severe conditions, it is unable to explain new developments 
in a satisfactory way. This triggers the search for a new paradigm, or at least a rehabilitation of the old one.

The rehabilitation of a scientific paradigm requires first of all identifying all problematic assumptions and replacing them with alternative hypotheses, ones that are able to integrate new knowledge. If all goes well, a new paradigm emerges from the ashes of the old discredited one. In other words, every crisis presents an opportunity to rehabilitate a flawed paradigm and bring it in line with reality.

While Kuhn was referring to the "hard" sciences, a similar conclusion can be drawn about economics. Success, whether in business or any other walk of life, requires first of all an ethical foundation. Where this foundation is lacking, for whatever reasons, a crisis in one form or another can be expected to follow sooner or later.

The most recent example of such a crisis was the 2008 global financial crisis. This crisis was caused, first and foremost, by the way risk was managed and, more generally, in the way resources were allocated. Financing investment took place by way of lending at interest. Risk management was carried out mainly by means of risk transfer, inclusive of the sale of debt or the use of credit derivatives. Neither of these practices is notable for its conformity with ethical principles.

An early casualty of the 2008 crisis was the view that markets - at any rate, credit markets - are efficient. The fundamental inefficiency of credit markets in the sense in which this term is used in finance was confirmed by the dramatic collapse in the prices of derivative securities known as collateralised debt obligations (CDOs) that were at the heart of the crisis. However, as this paper attempts to show, the damage inflicted on the existing paradigm went beyond the demise of the efficient market hypothesis. Another major casualty of the recent 2008 financial crisis is the view that the best way to manage risk is to transfer it to someone else.

The central question ahead is whether the right lessons will be drawn from the recent (2008) experience, and whether enough momentum can be generated to move to a new paradigm, one of risk sharing rather than risk transfer. This would ensure not only better protection for investors (a microeconomic objective) but also a more efficient allocation of resources (a macroeconomic objective), not only in the credit markets but especially where it counts most, in the real sector markets.

\section{Risk}

Risk is the possibility of an adverse or disastrous outcome of a given action. Risk arises out of the fact that our knowledge, in particular our knowledge of the future, is limited. While the past may be relatively well known, the future is unknown. It is tempting to predict the future on the basis of the past, according to 
the dictum "history repeats itself." However, no single model takes into account all variables that may influence the outcome of a given act.

The existence of risk implies a limit on our ability to control our fate. Some contingencies may be unforeseen. While science attempts to control the environment, inclusive of future events, history has shown repeatedly that human control is always incomplete. Complete control rests only with God.

Risks arise in all walks of life. ${ }^{2}$ A person driving through a red light takes a risk of getting involved in an accident. A smoker takes the risk of developing cancer. A gambler takes the risk of losing money. There is a risk of fire, or the risk of becoming a victim of crime. There is a risk of being kidnapped, being mistaken for someone else, or the risk of becoming an innocent victim.

There is also the risk of physical or psychological injury, illness or an outbreak of epidemic, on a local or a global scale. Natural disasters, such as floods, earthquakes or tsunamis, also present risks. There is also a risk of war, civil war, or even a world war. There is a risk of political instability (rioting or a coup d'état). There is a risk of property loss or damage, or a risk of disgrace (damage to one's reputation).

Everything from wearing protective clothing, starting a retirement fund, to spending on defence, is a different way of shielding oneself or one's community from risk and the fundamental insecurity that characterises all human existence.

Risks can be divided into avoidable and unavoidable. Avoidable risks, such as the risk of loss arising from gambling (qimar), are self-imposed. In order to avoid such risks one merely needs to abstain from the activities that give rise to them. Other risks, such as the risk of losses in business, may be unavoidable. In principle, unavoidable risks are permitted, but avoidable are not. Hence, risk taking is permitted in business but not in gambling. ${ }^{3}$

The fact that risk in business is unavoidable makes it fundamentally different from risks such as arise in gambling. In gambling, one party can win only if another loses. Gambling is thus a "win-lose" or "zero sum game." By contrast, partners in business gain or suffer a loss together. ${ }^{4}$

\section{Risks in Finance}

In finance, risks arise in both investment as well as lending. The main risk in investment is the risk of losses. The main risk in lending is the risk that borrowers may fail to repay their loans to creditors. This risk is known as credit risk, also known as the risk of default or more simply as counterparty risk.

A common method of protecting against credit risk is simply to withhold lending from all borrowers unable to post acceptable collateral. At the company level another method is for lenders to purchase credit derivatives such as credit default swaps (CDS), effectively a form of insurance on debt. 
Another risk that arises in lending is interest risk. This is the risk that interest rates may change in an unfavourable direction. A common method of protection against interest risk is to enter into interest rate swap (IRS) contracts.

Liquidity risk arises in both lending and investment. This risk arises from the fact that it may become difficult if not impossible to liquidate securities, whether stocks or bonds, at a time of crisis. ${ }^{5}$ Liquidity crises commonly take place when investors wish to liquidate their assets at the same time. Selling pressure drives prices down and makes it impossible to liquidate securities at any but rock bottom prices.

This is essentially what transpired during the recent 2008 global financial crisis, when a large number of investors became unable to liquidate their holdings of CDOs (collateralised debt obligations), as they all wanted to sell at the same time. ${ }^{6}$ Protection against liquidity risk commonly takes the form of portfolio diversification to ensure that little correlation exists between various investments in the portfolio.

Another risk that arises in both lending and investment is known as market risk. This risk is also known as systemic risk. This is the risk that entire markets may become adversely affected, thus causing losses to both investors as well as to lenders. Market risk presents a greater threat to short term speculators than long-term investors. One example of market risk is the risk that prices of bonds will change as a result of a change in interest rates. ${ }^{7}$

Foreign exchange risk, also known as currency risk, arises from the fact that exchange rates may change in an unfavourable direction. This risk faces exporters and importers, as well as investors in foreign countries. It also affects parties that borrow in foreign currencies. The risk is that the value of a foreign currency relative to the value of the local currency may appreciate, thus obliging the borrower to repay more (in terms of the local currency) than what he borrowed in foreign currency. A common method of protection against this risk is to enter into foreign exchange swaps.

\section{Risk Transfer}

Risk transfer takes place when a party that takes a risk "transfers" the responsibility for adverse consequences (losses) of a risky action onto another party. Normally, risk is transferred for a fee. Thus, risk transfer in principle amounts to the "sale" of risk. Risk transfer takes place when the party that transfers a given risk has faced the risk to begin with, even if only for a short period of time.

Thus, collateralised lending does not constitute risk transfer, because the financial institution does not face any risk to begin with. It may be more accurate to say that secured lending is characterised by risk aversion. Nevertheless, in so far as lenders do not share business risks with borrowers (entrepreneurs), 
collateralised lending in principle has the same effect as risk transfer: it burdens one of the counterparties (the entrepreneur) with the need to shoulder all of a given type of risk, in this case business risk.

There are many ways to transfer risk, depending on the type of risk. A widely used method of risk transfer, in particular the risk of default, is to sell loans to other parties. Risk transfer in the form of the sale of debt was used extensively from 2000 to 2006, in the lead up to the global financial crisis of 2008.

First, originators transferred the risk of default on the loans they made (subprime mortgages) by selling them to investment banks. Investment banks subsequently transferred the same risks to other parties by selling the same loans (this time on a wholesale basis) to institutional investors. The institutional investors included pensions funds, insurance companies and hedge funds. The loans were sold in the form of collateralised debt obligations (CDOs). These are pools of mortgage backed securities (MBSs) or mortgage bonds. The sales of the CDOs were facilitated by the fact that rating agencies assigned "AAA" ratings to them. ${ }^{8}$

Another way to transfer the risk of default is to purchase credit default swaps, effectively a form of insurance on debt. CDSs are typically issued (sold) by investment banks and insurance companies. Sellers (writers) of CDS insure debt in exchange for a premium payment fixed in advance. ${ }^{9} \mathrm{CDSs}$ oblige issuers (sellers) to compensate subscribers (buyers) to the extent of the latter's loss, in case a borrower defaults or a credit event (such as a downgrading) takes place. Most of the time, issuers are able to honour their obligations. There is no guarantee, however, that the issuer of the CDS will be able to live up to his obligations in case of a systemic crisis.

CDOs and CDSs are known as credit derivatives. ${ }^{10}$ Under normal conditions, they transfer all of a given risk, in this case the risk of default. Other credit derivatives such as interest rate swaps (IRSs) transfer only a part (half) of a given risk, the risk that interest rates may rise or fall. IRSs are traded OTC (over the counter) and make up the great majority of derivatives, currently at $\$ 548$ trillion. ${ }^{11}$

The reason why counterparties enter IRS contracts is that they expect interest rates to change in opposite directions. ${ }^{12}$ An IRS contract requires counterparties to exchange (swap) interest payments. Normally, a fixed rate is exchanged for a floating rate. Both rates are applied to a notional amount. The floating rate is determined in relation to a reference rate such as LIBOR (London Interbank Offered Rate). The fixed rate is agreed upon in advance. Should market rates rise, the party paying the fixed rate will gain, as the party paying the floating rate will have to pay more than before. Should the rates fall, however, the party paying the floating rate will gain, as it will be obliged to pay less than before.

Parties that enter IRSs become exposed to an additional risk that may arise from fraud, in the form of "fixing" the reference interest rate, as happened 
recently with LIBOR. This price fixing resulted in billions of dollars of losses on both sides of the Atlantic. ${ }^{13}$

\section{Problems in Risk Transfer}

The chief of the problematic assumptions in conventional risk management approaches is the view that the best way to "manage" risk is to transfer it to someone else, presumably someone who is willing and able to bear it. However, being willing to bear someone else's risk is not the same as being able to bear it, especially at a time of a systemic crisis such as a liquidity crisis. ${ }^{14}$ Secondly, while under normal circumstances risk transfer may decrease or eliminate risk for individual counterparties, it is clear that this takes place only at the expense of magnifying systemic risk.

Should a crisis occurs, the systemic risk rises and conventional risk transfer methods fail because at a time of crisis even asset prices that were previously not correlated suddenly become correlated and portfolio diversification ceases to serve as an effective hedge against losses. ${ }^{15}$ The only recourse then appears to take the form of government bailouts.

The 2008 global financial crisis showed that a willingness to bear risk does not yet guarantee the ability to bear it. There were plenty of institutions "willing" to bear risk, notably investment banks Lehman Brothers, Bear Stearns, and insurance giant AIG, but few that have actually able to do so when they were called upon to do it. ${ }^{16}$ Thus, there is a need for a better way to manage risk than by transferring it.

Risk transfer effectively amounts to a sale of responsibility. This is problematic for a number of reasons. One, risk transfer severs the link between a given action and the need to take responsibility for it. In doing so, it not only undermines the principle of individual responsibility, but also causes injustice. Risk transfer causes injustice in that it imposes the responsibility for a given act on a party that did not perform it in the first place.

By transferring the responsibility for a given act to a person other than the one who carries it out, risk transfer provides an incentive for irresponsible or highrisk behaviour. In other words, risk transfer gives rise to a moral hazard. The fact that the party that accepts the risk does so voluntarily makes little difference. The injustice of a given act is not diminished by the fact that its victim voluntarily agrees to suffer it.

This is what in effect took place when subprime mortgage loan originators sold their loans to investment banks, which in turn bundled them together and sold them to institutional investors. The risk of default (credit risk) was first transferred to investment banks, which subsequently transferred it to institutional investors, with the help of overly optimistic, and in retrospect misleading, AAA ratings from rating agencies. ${ }^{17}$ 
By providing investors with a false sense of security, risk transfer provided the incentive for many financial institutions to take progressively greater and greater risks with their shareholders' and depositors' funds. The sum of individual risks, however, collectively translated into a high degree of systemic risk.

A major weakness of risk transfer, accordingly, is that while it may work in ordinary times, it rarely works in extraordinary conditions. In extraordinary times, parties willing to take on risks from others often prove themselves unable to meet their obligations, giving rise to the spectre of a systemic collapse. Thus, risk transfer contracts fail to protect investors precisely at a time when they most need protection, a time of crisis.

This is what took place in the 2008 global financial crisis. ${ }^{18}$ The financial system nearly collapsed the way a ship may capsize when all its cargo is transferred from one side of the ship to the other. At a time of systemic crisis, even portfolio diversification no longer protects against asset price declines, as the prices of even unrelated assets tend to move (down) together.

At a time of crisis the counterparties in risk transfer contracts, like counterparties in risk sharing contracts, "sink or swim together." The difference is that the utilisation of risk transfer contracts dramatically raises the likelihood of a systemic crisis. It does this by transferring risks that should ideally be borne by all, as in risk sharing contracts, to only half of the counterparties, those that feel "able" to take the risks.

A domino effect of systemic collapse was stemmed only by government intervention in the form of bailouts of troubled financial institutions, such as insurance giant AIG and investment banks that depended on it. ${ }^{19}$ However, the bailouts had the effect of transferring the risks to taxpayers. ${ }^{20}$

Another problematic assumption in conventional risk management is the view that major catastrophes have a very low probability of taking place. ${ }^{21}$ According to conventional risk management models, the 1987 crash had "a negligible probability" of taking place, even over the entire lifetime of the universe. ${ }^{22}$ Another unwarranted assumption is the view that a very low or very high degree of probability can for all practical purposes be identified with certainty. ${ }^{23}$

Another questionable assumption is the view that risk can be measured while uncertainty cannot. The difference between risk and uncertainty is, however, quite arbitrary. Risk by definition can never be accurately measured. This was confirmed by the fact that the latest risk-valuation models failed to value securities, in particular the collateralised debt obligations or CDOs, accurately. ${ }^{24}$

An additional problem arises from the fact that the risk of mispricing derivatives is greater than the risk of mispricing a common share or a bond. The reason is that pricing of derivatives requires the pricing of two securities and not just one, as is the case with ordinary securities such as stocks. The underlying security has to be 
priced accurately first. Then, the (derivative) security whose price depends on the performance of the underlying asset has to be valued separately. For this reason the error margin in the pricing of derivatives effectively doubles. It goes without saying that if the underlying security (such as a subprime loan) is mispriced, the price of the derivative security will also be inaccurate.

Another weakness in contemporary risk management is that intuition has been largely marginalised. Intuition takes into account, even if in an imprecise way, the presence of variables that may have been overlooked in purely mathematical models. Purely mathematical models by definition cannot account for any variables that do not lend themselves to quantification and therefore measurement. ${ }^{25}$ Managing risk by way of intuition simply means avoiding investments about which one may have a "bad feeling," perhaps due to their inherent complexity and opaqueness, but cannot objectively articulate the source of the ill feeling.

Other problematic assumptions include the view that markets perform in the same way under normal conditions as in extraordinary circumstances, that credit markets operate fundamentally in the same way as other markets, and that trading (buying or selling) has essentially no effect on prices. The 2008 financial crisis showed, however, that trading, in particular trading under duress, can significantly impact prices even in a relatively short period of time. ${ }^{26}$

Another disadvantage of risk transfer is that its utilisation drains large amounts of resources from the real sector and channels them into the largely unproductive credit sector. This process is known as "financialisation." By drawing resources away from the real sector, financialisation reduces the aggregate demand for goods and services, and thus reduces real economic growth.

Moreover, unlike risk sharing, risk transfer establishes different relationships between counterparties. Whereas risk sharing, because it requires sharing, calls for a partnership relationship between counterparties, risk transfer establishes a win/lose relationship between counterparties. This type of relationship is at odds with the ethos of Islam, which emphasises brotherhood and sharing.

Because of the many weaknesses of risk transfer, a better way of managing risks needs to be found. Such a way is already available in Islamic finance. ${ }^{27}$ Islamic finance teaches that the best way to manage business risk is to share it. ${ }^{28}$

\section{Risk Sharing}

Sharing is important in Islam. It takes place in many walks of life. Muslims share a common heritage and a common way of life. They also share many aspirations. Islam endorses sharing as the believers are but one brotherhood. ${ }^{29}$ Islam recognises the essential dignity of man, and calls for sharing one's knowledge (through teaching and missionary activities).

The Qur'an calls for sharing of one's wealth, through charitable donations 
(zakāh and șadaqah) and endowments (awqāf). Man is viewed as a vicegerent (khalīfah) of God on the earth. ${ }^{30}$ Man enjoys property (al-māl) as a trust (amānah) from God. Islam requires taking responsibility for one's actions. We are held accountable for our actions on Judgment Day and rewarded accordingly.

Islam permits business risk taking and encourages risk sharing. ${ }^{31}$ Risk sharing is consistent with the idea of taking responsibility for one's actions. Islamic law proscribes bay al-dayn (the sale of debt), as it entails a transfer of risk that amounts to a moral hazard. Risk transfer by contrast obliges one party to bear the burdens (risks) of another. By doing so, it creates a moral hazard and may encourage recklessness. The need to share risk, on the other hand, restrains recklessness. Thus, risk sharing is fundamentally in accord with the teaching of Islam. Risk transfer is not.

Risk sharing in business is a way of taking collective responsibility for the outcome of a given investment. Risk sharing by partners in a business enterprise reduces the amount of risk faced by any one party. ${ }^{32}$ The greater the number of partners sharing the risk, the lower is the risk facing each partner. Partners can also offer advice to one another (nașinhah) on the most effective ways to reduce the risks facing their business enterprise. Consultation $(s h \bar{u} r \bar{a})$ should in turn enhance the level of trust among the partners.

When an investor takes on a single equal partner, he reduces his risk by fifty per cent. When three parties share the risk equally, the risk is reduced by two thirds of what a single party would have to bear. The greater the number of parties sharing the risk, the lower will be the risk facing each party. The amount of risk decreases as the number of partners sharing it increases.

Risk is a powerful deterrent. Investors are motivated by a hope of profits and restrained by the risks of losses. ${ }^{33}$ Thus, sharing risks promotes a balanced approach to investment. The possibility (risk) of suffering losses acts as a powerful incentive to investors to allocate resources wisely. Where investors feel there is little or no risk, they are more likely to commit resources on a scale greater than what is justified by a more accurate assessment of risks and the prospects of returns. Risk constitutes an important incentive for exercising due diligence, a sine qua non of an efficient allocation of capital.

One consequence of the underutilisation of risk sharing during the 2008 global financial crisis was a misallocation of resources on a scale not seen before. This is evident in the millions of houses that were constructed in the US and financed by subprime mortgages. These houses have since been repossessed by financial institutions and are now being torn down due to dilapidation. Several trillion dollars have been wasted this way.

The need to face (share) risk filters out excessively risky investments. Illconceived projects are unlikely to attract funding. The fact that a given project is 
unable to raise funds by way of risk sharing shows that it should not be financed in the first place. Risk transfer by contrast produces an illusion of safety (low risk) and therefore a moral hazard. As a result of a false sense of security, investors may grow complacent and take progressively higher risks, while becoming oblivious to the larger systemic risks. As a consequence, "white elephant" projects may be financed, representing a significant waste of resources that could have instead been used in socially useful ways.

\section{Benefits of Risk Sharing}

Risk sharing can be realised by entering partnership contracts. ${ }^{34}$ As partners, suppliers of capital share both risks and rewards with entrepreneurs. ${ }^{35}$ The terms on which capital providers supply investment funds to entrepreneurs depend on the type of partnerships they enter. A partnership can be active or passive. Where the investors actively participate in the running of the business, the partnership is known as a musharakah.

Partners share profits according to a pre-agreed ratio, but losses are shared in proportion to the capital invested. A partnership in which capital suppliers do not participate in the management of the business enterprise is known as mudarabah or profit sharing partnership. Risk can also be shared by participating in a joint stock company. Investors are effectively owners of the business enterprise, and they share both profits and losses.

Different types of partnership issue different types of securities in exchange for investment funds. Musharakah partnerships issue sukuk musharakah. Mudarabah partnerships issue sukuk mudarabah. Conventional partnerships (joint stock companies) issue common shares. Participation in companies on the basis of shareholding is permissible under the Shariah because it requires investors to share not only profits but also the risks of business enterprise.

Securities issued by partnerships are contracts between the providers of capital and its users, the entrepreneurs. The securities specify that in return for supplying investment funds, capital providers become co-owners, on a proportionate basis, of the profit generating assets or businesses. As co-owners, investors become entitled to a proportionate share of the profits generated by the assets or businesses. The first two types of partnerships are characteristically Islamic, while the third is used in both conventional and Islamic finance.

The activities of a musharakah partnership are governed by the musharakah agreement, which must include a detailed business plan. ${ }^{36}$ The agreement needs to be drawn up in such a way as to comply with the requirements of both the Shariah as well as the law of the country where the certificates are issued. ${ }^{37}$

Sukuk musharakah are investment certificates that signify proportionate ownership in a pool of underlying assets and the entitlement of the sukuk holders 
to a proportionate share of the profits generated by those assets. ${ }^{38}$ Producing intoxicating substances or pork or providing services such as gambling are excluded. ${ }^{39}$

Sukuk musharakah are similar to ordinary or common shares, except that the sukuk certificates are issued for a specific period of time, while shares are issued without a maturity date. Both common shares and sukuk musharakah can be traded in secondary markets.

The advantage of musharakah is that partners do not go into debt. Another advantage is that they face no risk of default. Another advantage is that musharakah partners are not obligated to pay dividends when no profits are earned. This is a major advantage of funding enterprise by musharakah.

The musharakah and the mudarabah partnership are both fiduciary contracts. ${ }^{40}$ In the case of the mudarabah, the capital provider ( $r a b b a l-m \bar{a} l)$ trusts another party, the manager (mudarib), with faithfully discharging his duties and managing the entrusted capital to the best of his ability for the purpose of earning a profit. ${ }^{41}$

For his efforts, the mudarib gets a share of profits, according to a pre-agreed formula or ratio. This is his incentive for performing due diligence and investing wisely. The profit ratio is applied to profits earned rather than to the capital provided. When the enterprise earns no profits, the mudarib is not rewarded. ${ }^{42}$

As long as he acts in good faith, the mudarib is not responsible for any losses. All losses are borne by the capital provider. In case of wilful negligence or fraud, however, the mudarib becomes liable.

The capital provider is expected to leave the decision-making up to the managing partner, the mudarib. The mudarabah is typically set up for a specific period of time. Terms and conditions of the mudarabah partnership are set out in the mudarabah agreement, which is similar to the musharakah agreement, with some differences, however. ${ }^{43}$

The advantages of mudarabah are similar to those of musharakah. The entrepreneur need not go into debt. This arrangement is suitable for parties where a capital owner may have neither the time nor the expertise to manage wealth, while the party capable of managing wealth has no wealth of his own to manage.

Common shares, also known as equity shares, likewise constitute risk-sharing securities. Shareholders become co-owners of the company that generates their profits. Their profits are proportionate to their shareholdings. Owners of common shares are not guaranteed any profits in advance. Because profits are not guaranteed, investors face risk. Effectively, they "share" the risks of the business enterprise with all other shareholders. They are paid dividends only when their companies earn profits.

When a company makes profits, shareholders benefit from any dividend payments and/or the appreciation of the value of their shares. The price of their 
shares, under normal conditions and over the longer term, generally reflects the addition of any retained profits to the assets of the company, thus increasing its net worth. ${ }^{44}$

The total number of shares that a company is legally permitted to issue is known as "authorised capital." The total amount of money that has been raised by selling shares to investors is known as "paid up capital." In most jurisdictions, companies are legally permitted to issue new shares only in a way that does not dilute the value of other shareholders. ${ }^{45}$

Shareholders elect the board of directors, which in turn appoints the executives of the company to manage the company's day-to-day affairs. All publicly traded companies need to hold annual general meetings (AGMs) and file yearly reports or financial statements. Privately owned companies are exempted from this requirement. Shares of publicly traded companies are traded on stock exchanges.

Common stocks are also known as "voting shares" or "ordinary shares." Each common share certificate represents one share of the net worth of the company. ${ }^{46}$ The ownership of the productive assets entitles shareholders to a proportionate share of the company's profits. ${ }^{47}$

In contrast to risk transfer, risk sharing has many benefits. Chief among these is that a partnership relationship required by risk sharing is more in keeping with the ethos of Islam than a creditor debtor relationship that characterises all forms of lending. Where risk transfer undermines the spirit of brotherhood, risk sharing fosters it.

The fact that the payments of reward in risk sharing modes of financing depend on the performance (efficiency) of the enterprises being financed also results in a more efficient allocation of resources. It is also more in line with justice than a system where reward to investors is not linked in any meaningful way to the efficiency (profitability) of the enterprises they finance.

Partnership relationships do not introduce a win/lose relationship the way risk transfer strategies of risk management does. By spreading risk among a greater number of partners, another major advantage of risk sharing is that where risk transfer undermines systemic stability, risk sharing enhances it.

One reason why financial institutions hitherto may have shunned embracing profit and loss sharing partnerships more vigorously, apart from legal restrictions, may be the fact that the risks in financing business investment by risk sharing are perceived as simply too great. This is understandable. However, in light of the fact that current practice merely transforms individual risks into systemic risks, a way needs to be found that enables the participation of financial institutions in risk sharing and the protection of depositors' funds at the same time.

A solution may be found in offering risk-free accounts to depositors in the form of transaction (current) accounts for parties with a high aversion to risk, 
while offering a range of investment accounts to others who are willing to takes risks in order to earn higher profits. Moreover, equity participation in industrial enterprise has been successfully practiced in some nations such as Germany, where financial institutions buy a stake in the very companies they finance with loans. This gives them the right to participate in the management of these companies, to the extent of their shareholding. It also gives them a powerful incentive to ensure that the businesses they finance become successful. Finally, few would dispute that financial institutions in Germany have proved themselves to be among the most stable in the world.

\section{Conclusions and Recommendations}

The dominant paradigm of risk management has been severely tested in the 2008 global financial crisis. It has shown itself to be wanting in many respects. Apart from magnifying systemic instability, it also caused a waste of resources on a scale not seen before.

The crisis of 2008 brought to light a number of anomalies, in the form of unwarranted assumptions. Of these, the view that the best way to manage risk is to transfer it to someone else, turned out to be perhaps the most damaging. Therefore it is necessary to adopt a new model or paradigm, one that is better equipped to meet the challenges presented by new developments, such as the increasing financialisation of economic activity. Such a model is available in the form of the risk-sharing paradigm. Thus there is a need for a paradigm shift, from risk transfer to risk sharing.

The greatest disadvantage of risk transfer is that it does not permit risk sharing to take place. The many benefits of risk sharing, among them notably a more efficient allocation of resources as well as greater systemic stability, are lost when risk transfer methods of managing risk are used in preference to risk sharing. Appropriate legislation needs to be passed to facilitate and reward the transition to risk sharing modes of financing and the corresponding phasing out of risk transfer.

Risk transfer reduces risks faced by some parties only by increasing them for everyone else, including taxpayers. The reason is that while risk transfer may reduce risks faced by some parties individually, it does so only by increasing the systemic risk all parties face collectively. In the case of a systemic crisis, even parties that might have been able to shoulder risks under normal circumstances are unlikely to do so under conditions of stress. When risk sharing is applied on a system-wide basis, the risk of a systemic collapse is reduced by the fact that a greater number of parties share the total risk. By obliging a greater number of parties to share risks, risk sharing disperses risks more widely than risk transfer. 
From a social point of view, the most important benefits of financing investment by risk sharing comprise greater systemic stability and a better overall allocation of resources. Risk sharing ensures an efficient allocation of resources and a reduction of waste by providing investors with a powerful incentivethe risk of losses - to exercise due diligence. At the same time, by requiring a greater number of parties to share total risk, risk sharing enhances systemic stability. These constitute compelling reason for utilising risk-sharing contracts in preference to risk transfer modes of risk management.

- Banks and other financial institutions need to pay greater attention to systemic risks caused by risk transfer and apply risk sharing methods of financing more vigorously than has hitherto been the case.

- Inefficiencies in the allocation of resources caused by risk transfer also call for a reassessment of financing strategies.

- Financial securities need to be structured to share risk rather than to transfer it.

- A regulatory framework needs to be implemented that rewards and facilitates the issuance of securities that share risk rather than transfer it.

- Pilot projects could be organised to demonstrate the viability and benefits of risk sharing models.

\section{Notes}

* Abdul Karim Abdullah (Leslie Terebessy), Assistant Fellow at IAIS, earned his MA in political philosophy from the University of Toronto, Canada (1999) and a MEd (1986) from the University of Toronto's Ontario Institute for Studies in Education (OISE). A former lecturer, editor, writer and coordinator of the English program at University Sains Islam Malaysia (USIM), his current projects involve research into the current financial crisis, critical thinking in Muslim societies, and Islamic Finance. He has edited Islamic Studies at World Institutions of Higher Learning (Kuala Lumpur:

USIM 2004).

1. Thomas Kuhn, The Structure of Scientific Revolutions (University of Chicago Press, 1962).

2. Mohammad Hashim Kamali, Islamic Commercial Law: An Analysis of Future and Options, (Ilmiah Publishers, 2000), 146.

3. Kamali, 151-157.

4. Andreas A. Jobst, "Derivatives in Islamic Finance," Islamic Economic Studies, Vol. 15, No. 1, 29; accessed 10 March 2013; available at SSRN: <http://ssrn.com/abstract=1015615>

5. Mushtak Parker, "Issues in Regulating Islamic finance," Central Banking.com, 18 February 2011, accessed 14 March 2013, <http://www.centralbanking.com/central-banking-journal/ feature/2042394/issues-regulating-islamic-finance>

6. CDOs are bundles or pools of debt, mostly bonds. CLOs or collateralised loan obligations are similar to CDOs, except that the former are bundles of loans rather than bonds. de la Ignacio Torre, "The Role of Derivatives in the Credit Crisis," 46, accessed 9 March 2013, <http://kantakji.com/ fiqh/Files/Markets/B120.pdf >

7. Bond prices are inversely related to interest rates.

8. Christopher Bliss, "Globalization and the Current Crisis," in The Economic Crisis and the State of Economics, 13-29, eds. Robert Skidelsky and Christian Westerlind Wigstrom (Palgrave Macmillan, 2010), 70 . 
9. The standard practice is to hedge the sale of swaps by entering offsetting transactions (buying swaps or insurance) with other parties. This was the trading strategy employed by most investment banks, such as J.P. Morgan Chase. A trader would sell insurance on a given debt for say $5 \%$ per annum, and then buy offsetting insurance (CDS) from another party for $4.5 \%$. The income to the investment bank would be the difference between what it earns (5\%) and what it pays $(4.5 \%)$. The $0.5 \%$ of income on a debt of $\$ 100$ million would amount to $\$ 500,000$ per annum.

10. A derivative is a security whose value depends on the value of an underlying asset, which can be a real asset such as a commodity, another security such as a bond, or an index such as an interest rate. Derivatives include credit default swaps, interest rate swaps, and futures as well as options.

11. Toby Birch, "The Role of Derivatives in Creating the Financial Crisis," 26, accessed 9 March 2013, $<$ http://kantakji.com/fiqh/Files/Markets/B120.pdf >

12. Interest rate swaps trade in the unregulated "over the counter" (OTC) market, directly between counterparties.

13. There have been many well known cases where major losses were experienced by parties that entered the swap agreements, When to this is added the fact the LIBOR rates have been manipulated by financial institutions, the case for avoiding interest rate swaps becomes even stronger.

14. de la Ignacio Torre, "Role of Derivatives".

15. Paul Davidson, "Risk and Uncertainty," in The Economic Crisis and the State of Economics, eds. Robert Skidelsky and Christian Westerlind Wigstrom, (Palgrave Macmillan, 2010), 18.

16. Other investment banks that overextended themselves included Merrill Lynch and Goldman Sachs. These were either taken over by larger institutions, as Merrill Lynch was bought by Bank of America, or had to take other steps to ease their liquidity problems, as was the case with Goldman Sachs when it temporarily converted itself into a commercial bank in order to qualify for loans offered by the federal government to troubled institutions under TARP (Troubled Asset Relief Program).

17. Rating agencies have been taken to court by many investors who felt that the CDOs they invested in, which were given triple A ratings by rating agencies, were inaccurately valued, thus causing investors' losses.

18. Augustin Landier, David Sraer, David Thesmar, "The Risk-Shifting Hypothesis: Evidence from Subprime Originations," 2011, p. 3, accessed 12 March 2013, <http://www.scor.com/images/ stories/pdf/library/chairscor/chairtse_theriskshiftinghypothesisevidencefromsubprimeoriginations. pdf $>$

19. As a result of their losses, a number of investors launched lawsuits against some of the rating agencies on the grounds that they wrongly assigned a triple "A" (investment grade) rating to the CDOs purchased by investors.

20. Franklin Allen and Elena Carletti, "Credit Risk Transfer and Contagion," Centre for Financial Studies (CFS) (Goethe University Frankfurt, working paper, No. 2005, 25, 2005), 19. accessed 10 March 2013,

21. <https://www.econstor.eu/dspace/bitstream/10419/25423/1/504023675.PDF>

22. Paul Davidson, "Risk and Uncertainty", in The Economic Crisis and the State of Economics, 1329, eds. Robert Skidelsky and Christian Westerlind Wigstrom (Palgrave Macmillan, 2010), 15-20.

23. Marc Potters, "Lessons from Statistical Finance," The Economic Crisis and the State of Economics, 13-29, eds. Robert Skidelsky and Christian Westerlind Wigstrom, (Palgrave Macmillan, 2010) . 32.

24. Davidson, 15.

25. Davidson, 18.

26. Richard Bronk, "Models and Metaphors," The Economic Crisis and the State of Economics, pp. 13-29, eds. Robert Skidelsky and Christian Westerlind Wigstrom (Palgrave Macmillan, 2010) 109.

27. Potters, 32 .

28. Stephen Brooks, "A Lesson from Sharia Banking," Global Banking \& Finance Review," accessed online on 14 March 2013, <http://www.globalbankingandfinance.com/Islamic-Finance/A-lessonfrom-Sharia-Banking.html>

29. Andreas A. Jobst, "The Economics of Islamic Finance and Securitization," Working Paper Version: February 28, 2007 Forthcoming in the Journal of Structured Finance (2007), Vol. 13, No. 1, p. 4, accessed 19 January 2013, <http://www.kantakji.com/fiqh/Files/Markets/f178.pdf> 
30. Qur'an, 21:92, 23:52, and 49:10. Trans. A. Yusuf Ali.

31. Qur'an, 2:30.

32. Ayman H. Khaleq and Todd Crosby, "Musharakah Sukuk: Structure, Legal Framework and Opportunities," in Sukuk, ed. Abdulkader Tomas (Securities Commission Malaysia, Sweet and Maxwell Asia, Thomson Reuters, 2009) 189.

33. Kamali, Islamic Commercial Law, 209.

34. M. Umer Chapra, Towards a Just Monetary System (The Islamic Foundation, 1985) p. 69.

35. Oliver Ali Agha and Claire Grainger, "Analysis: Sukuk - When is a default not really a default?" Risk.net, 11 Dec 2009, accessed 15 March 2013, <http://www.risk.net/credit/analysis/1565919/ sukuk-default-default>

36. Nabeel Shoaib, "Top 500 Islamic Financial Institutions - From Niche To Mainstream," The Banker, Nov 2007, 1, accessed 15 March 2013, <http://search.proquest.com.myaccess.library.utoronto.ca/ docview/225624269\#>

37. Khaleq and Crosby, 188.

38. Ibid., 191.

39. The musharakah agreement must identify the musharakah partners, record the agreement of the partners to enter into the musharakah contract, specify the respective contributions of capital by the partners, identify the nature of the musharakah venture, specify the manner of profit and loss sharing, and provide details as to the dissolution date of the musharakah. Additional rights and obligations of the partners may be included, such as the frequency of payments or the identity of the manager of the musharakah venture. N.a. The Islamic Securities (Sukuk) Market, Securities Commission Malaysia, LexisNexis, 2009, 23.

40. A. Khaleq and Crosby, 197.

41. Jobst, 6 .

42. Harun Kapetanovic and Muhamed Becic, "Mudharabah Sukuk: Essential Islamic Contract, Applications and Way Forward," in Sukuk, 226.

43. Jobst, "Derivatives".

44. The mudarabah agreement needs to identify the parties of the mudarabah, the capital provider ( $\mathrm{rabb} \mathrm{al} \mathrm{mal}$ ) and the manager (mudarib). It must also record their agreement to enter into the mudarabah agreement. In addition, it needs to state the purpose of the mudarabah and specify its date of dissolution. Moreover, the amount contributed by the rabb al mal, and the agreed profit sharing ratio should also be clearly specified. The agreement may also include an undertaking to re-purchase the mudarabah assets. All assets, however, can be repurchased only at the prevailing market prices. The amount to be paid for the remaining assets of the mudarabah cannot be determined in advance, as this would once again impart to the transaction a significant characteristic of loans, a guarantee of capital. N.a. The Islamic Securities (Sukuk) Market, Securities Commission Malaysia, LexisNexis, 2009, 2127-128.

45. The net worth of the company is the difference between its total assets and its total liabilities.

46. Thus, executives would not be permitted to issues shares to themselves or other parties at a price that is lower than the weighted current average price of its shares. To issue such shares at a discount would be to dilute the value of the shares of the other shareholders.

47. The book value per common share is equal to the net worth of the company (total assets - total liabilities) divided by the total number of shares outstanding. This is not necessarily the same as the market price of the stock, which may be higher, lower, or equal to the book value of the stock, depending on market conditions and other factors.

48. Over time, common stocks perform better than preferred shares as well as bonds, by a margin of $6 \%$ to $9 \%$ in real terms. 